INEEL/EXT-2000-00567

May 2000

\title{
Gamma-Ray Spectrometric Characterization of Overpacked CC104/107 RH-TRU Wastes - Surrogate Tests
}

\author{
J. K. Hartwell \\ R. T. Klann \\ M. E. Mcllwain
}




\title{
Gamma-Ray Spectrometric Characterization of Overpacked CC104/107 RH-TRU Wastes: Surrogate Tests
}

\author{
John K. Hartwell \\ Raymond T. Klann* \\ Michael E. Mcllwain
}

Published May 2000

Idaho National Engineering and Environmental Laboratory Nuclear and Radiological Sciences Department Idaho Falls, Idaho 83415

*Argonne National Laboratory

9700 S. Cass Avenue, BIdg. 362

Argonne, IL 60439-4841

Prepared for the

U.S. Department of Energy

Assistant Secretary for

Environmental Restoration and Waste Management

Under DOE Idaho Operations Office

Contract DE-AC07-99ID13727 


\begin{abstract}
Development of the gamma-ray spectrometric technique termed GSAK (Gamma-Ray Spectrometry with Acceptable Knowledge) for the characterization of CC104/107 remote-handled transuranic (RH-TRU) wastes continued this year. Proof-of-principle measurements have been completed on the surrogate RH-TRU waste drums configured earlier this year.

The GSAK technique uses conventional gamma-ray spectrometry to quantify the detectable fission product content of overpacked RH-TRU drums. These results are then coupled with the inventory report to characterize the waste drum content. The inventory report is based on process knowledge of the waste drum loading and calculations of the isotopic distribution in the spent fuel examined to generate the drummed wastes.

Three RH-TRU surrogate drums were configured with encapsulated EBR-II driver fuel rod segments arranged in the surrogate drum assemblies. Segment-specific inventory calculations initially specified the radionuclide content of the fuel segments and thus the surrogate drums. Radiochemical assays performed on representative fuel element segments identified a problem in the accuracy of some of the fission and activation product inventory values and provided a basis for adjustment of the specified surrogate drum inventories.
\end{abstract}

The three waste drum surrogates, contained within their $8.9 \mathrm{~cm}$ (3.5 inch) thick steel overpacks, were analyzed by gamma-ray spectrometry at the TREAT facility at Argonne National Laboratory-West. Seven fission and activation product radionuclides $\left({ }^{54} \mathrm{Mn},{ }^{60} \mathrm{Co},{ }^{125} \mathrm{Sb},{ }^{134} \mathrm{Cs},{ }^{137} \mathrm{Cs},{ }^{144} \mathrm{CePr}\right.$, and $\left.{ }^{154} \mathrm{Eu}\right)$ were reliably detected. The gamma-ray spectral accuracy was very good. In all cases, a two-sigma error bar constructed about the measured value included the actual drum activity. 


\section{ACKNOWLEDGEMENTS}

The authors would like to acknowledge the support of the National Mixed Waste Focus Area and their personnel to the GSAK development effort. The authors also thank the personnel of Argonne National Laboratory's Hot Cells and TREAT reactor facilities. Without their careful attention to detail, these surrogate measurements would not have been successful.

This document was prepared for the U. S. Department of Energy Office of Environmental

Restoration and Waste Management under DOE Idaho Operations Office Contract DE-AC07-99ID13727. The submitted manuscript has been authored by a contractor of the U.S. Government under contract No. W-31-109-Eng-38. Accordingly, the U.S. Government retains a non-exclusive, royalty-free license to publish or reproduce the published form of this contribution, or allow others to do so, for U.S.

Government purposes. 


\section{CONTENTS}

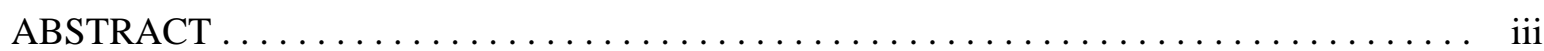

ACKNOWLEDGEMENTS $\ldots \ldots \ldots \ldots \ldots \ldots \ldots \ldots \ldots \ldots \ldots \ldots \ldots \ldots \ldots \ldots$

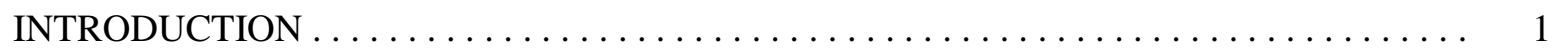

EXPERIMENTAL METHODS $\ldots \ldots \ldots \ldots \ldots \ldots \ldots \ldots \ldots \ldots \ldots \ldots \ldots \ldots \ldots \ldots$

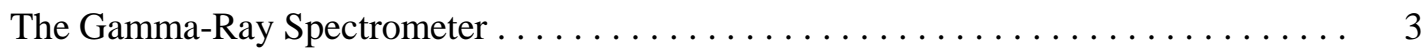

Calibration Measurements ........................ 3

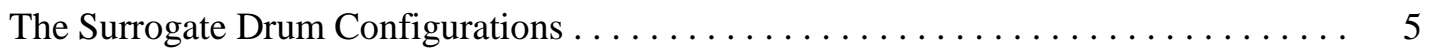

Test Sources and Their Placement .................... 5

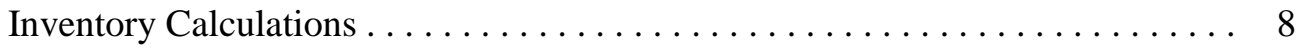

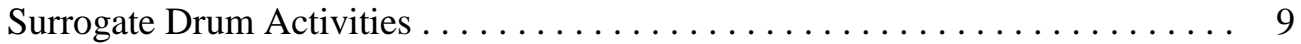

Surrogate Drum Measurements at the TREAT Facility . . . . . . . . . . . . 10

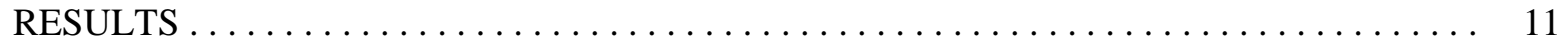

Radiochemical Segment Assays . . . . . . . . . . . . . . . . . . . . . 11

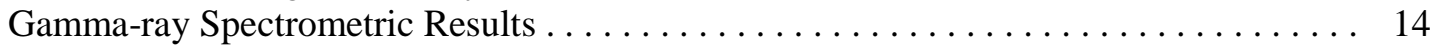

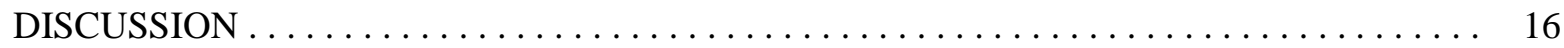

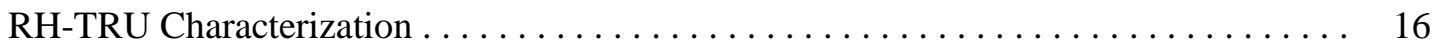

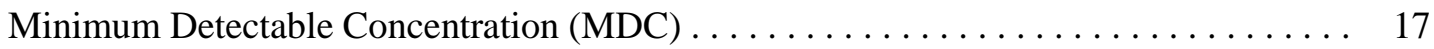

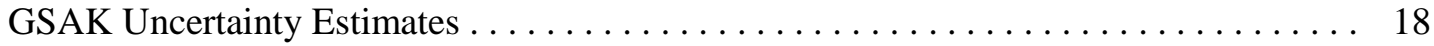

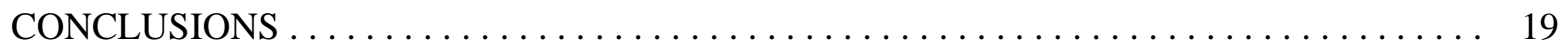

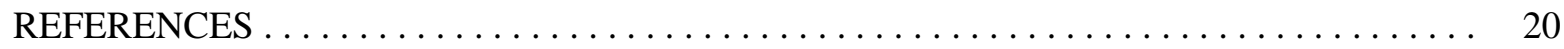




\section{Gamma-Ray Spectrometric Characterization of Overpacked CC104/107 RH-TRU Wastes: Surrogate Tests}

\section{INTRODUCTION}

In FY 1999 the Gamma-Ray Spectrometry combined with Acceptable Knowledge (GSAK) technique for the nondestructive assay of certain RH-TRU wastes was demonstrated at the INEEL on surrogate CC104/107 waste drums. This report documents the results of that demonstration.

The GSAK technique uses conventional gamma-ray spectrometry to determine a portion of the fission and activation product content of shielded RH-TRU waste containers. The total contents are then determined using the measured activity values and isotopic ratios determined from the irradiation history of the spent fuels that created the interrogated waste material. The GSAK technique is not applicable to all RH-TRU waste forms either here at the INEEL or elsewhere in the complex. It will provide sufficient characterization for RH waste forms about which enough information is known to allow the calculation of waste container contents from knowledge of the waste form and measured concentrations of a few fission and activation products. A waste stream that appears to meet this level of acceptable knowledge is the content code 104/107 (CC104/107) waste stream that comprises about 90\% of the INEEL's RH-TRU waste inventory. A 1997 review and analysis of shipping records and hot cell documentation concluded that sufficient documentation could be supplied to satisfy the DOE's Carlsbad Area Office (CAO) criteria for acceptable knowledge documentation for this waste stream.

The INEEL's CC104/107 waste inventory is primarily heterogeneous debris resulting from hot cell examinations of nuclear fuel assemblies irradiated in the Experimental Breeder Reactor II (EBR-II). The debris waste containers contain either combustible or noncombustible materials. The debris wastes are contained in 28-liter (7.5-gallon) steel pails, two of which are stacked in lined 114-liter (30-gallon) drums. Figure 1 depicts the waste container configuration.

During handling and measurements, each drum is contained in a shielding overpack with $8.9-\mathrm{cm}$ (3.5-inch) thick steel walls. The GSAK gamma-ray spectral measurements were performed on surrogate waste forms contained in a steel overpack. The shielded and mildly collimated gamma-ray spectrometer measured the overpacked surrogates at distances of one or two meters from the wall of the rotating overpack. An artist's depiction of the measurement configuration is presented in Figure 2. 

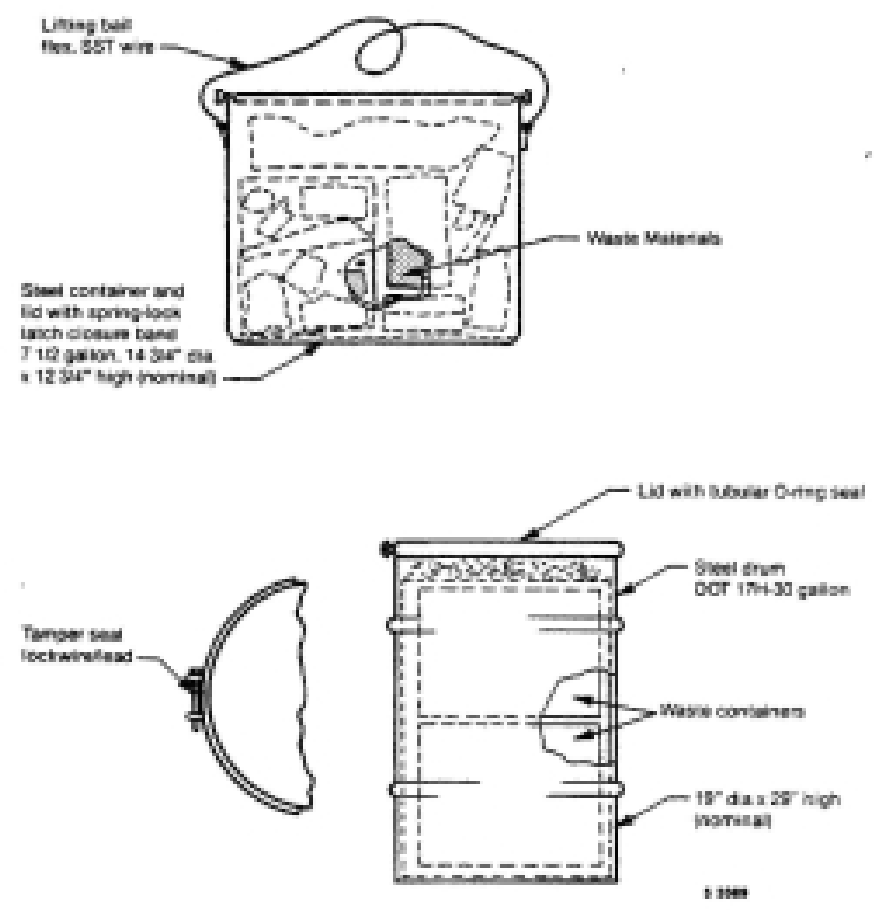

Figure 1. Waste packaging for CC104/107 wastes stored at the INEEL.

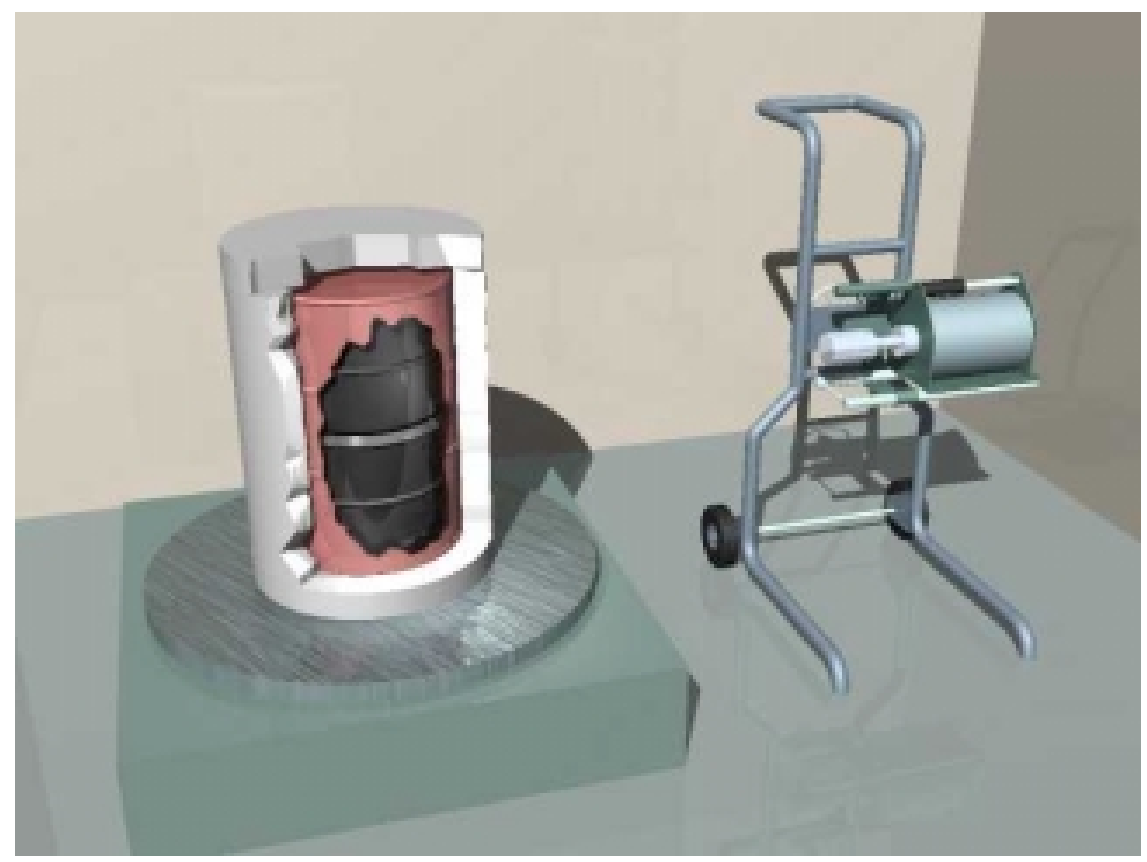

Figure 2. Artist's conception of a shielded waste drum undergoing gamma-ray spectrometric assay. The detector shield and collimator have been removed for clarity. 


\section{EXPERIMENTAL METHODS}

\section{The Gamma-Ray Spectrometer}

The gamma-ray spectrometer consists of a high purity 50 -mm diameter by 20 -mm thick n-type high-purity germanium detector (HPGe,) a detector shield and support cart, and a self-contained electronics and multichannel analyzer system. The equipment comprises a spectroscopy system dubbed the In-Situ Object Counting System (ISOCS) by the manufacturer (Canberra Industries). The detector has been specially characterized for efficiency modeling using software provided with the system. ${ }^{2}$ The ISOCS software allows calculation of detection efficiency curves for complex geometries when the detector has been characterized by Canberra Industries.

The detector is what is termed a "LEGe" detector. It has a thin carbon composite window and a $20 \%$ relative efficiency with a length-to-diameter ratio of only 0.4 . Although not ideal for the GSAK measurements, this detector was pressed into service when the primary GSAK detector developed a thermal short and failed.

\section{Calibration Measurements}

A GSAK calibration standard was prepared from a ${ }^{152} \mathrm{Eu}$ stock solution calibrated by gamma-ray spectrometry in the INEEL's Radiation Measurements Laboratory (RML). The RML detector calibrations are directly traceable to the National Institute of Standards (NIST). The calibrated solution was diluted to 15 liters and added to a plastic-lined 28-liter (7.5-gallon) RH-TRU waste "pail." The standardized activity for ${ }^{152} \mathrm{Eu},{ }^{154} \mathrm{Eu}$, and ${ }^{155} \mathrm{Eu}$ are reported in Table 1 . Two uncertainty values are also reported. The "Counting Precision" is the estimated relative standard deviation (RSD) computed from the spectral counting precision alone, while the "Total Uncertainty" includes additional uncertainty components (such as efficiency calibration and normal positioning errors) as specified in the RML report of activities. The 28-liter (7.5-gallon) pail containing the standard was placed within a lined 114-liter (30gallon) drum positioned within a prototype steel overpack. The prototype overpack was identical to those to be used in the surrogate and waste retrieval measurements EXCEPT the prototype had 7.6-cm (3-inch) thick walls rather than the 8.9 -cm (3.5-inch) thick walls of the actual overpacks.

Table 1. Total activities of Eu isotopes in the RH-TRU calibration standard.

\begin{tabular}{cccc}
\hline Isotope & $\begin{array}{c}\text { Activity on 01-May-99 } \\
(\mathbf{B q})\end{array}$ & $\begin{array}{c}\text { Counting Precision } \\
(\mathbf{1} \text { RSD) }\end{array}$ & $\begin{array}{c}\text { Total Uncertainty } \\
(\mathbf{1} \text { RSD) }\end{array}$ \\
\hline${ }^{152} \mathrm{Eu}$ & $3.97 \mathrm{E}+07$ & $0.5 \%$ & $5.0 \%$ \\
${ }^{154} \mathrm{Eu}$ & $4.93 \mathrm{E}+06$ & $1.5 \%$ & $5.2 \%$ \\
${ }^{155} \mathrm{Eu}$ & $3.96 \mathrm{E}+05$ & $13 \%$ & $14 \%$ \\
\hline
\end{tabular}

Actual CC104/107 waste is packaged in two 28-liter (7.5-gallon) pails stacked in a lined 114-liter (30-gallon) drum (see Figure 1). Calibration measurements were made with the source-containing pail and an additional empty pail. Measurements were acquired with the pail containing the source on the bottom in the waste drum, and then repeated with the pails switched so that the source was on top. These results were within counting precision errors, but an average was used for efficiency calculations. 
Spectra were acquired at both 1 meter and 2 meter distances. The detector was positioned in its ISOCS shield and the face of the detector positioned one meter and then two meters from the wall of the overpack by changing the position of the ISOCS cart. The overpacked drum was rotated during measurements. The ISOCS shield is a 5 -cm (2-inch) thick lead shield with an internal diameter of $10 \mathrm{~cm}$ (4 inches). The shield extended about $18 \mathrm{~cm}$ (7 inches) forward of the detector face providing moderate collimation.

The gamma-ray spectra were analyzed using the PCGAP code ${ }_{\text {and }}$ efficiency values computed following normal procedures. The measured efficiency curves were compared with curves calculated using the ISOCS efficiency calculation software. The comparison was not good. For illustration, the measured and ISOCS calculated efficiency curves for the calibration work at 1 meter are compared in Figure 3. While agreement is reasonable (within 5\%) in the middle of the energy range, the curves disagree by nearly $50 \%$ at energies above $1000 \mathrm{keV}$. A portion of this poor performance may be due to compromises required in the geometry specification, since no ISOCS calculational template allowed an exact geometry specification. However, the ISOCS documentation says that in highly shielded geometries and at higher gamma-ray energies, errors of up to a factor of 2 can be expected because of incomplete treatment of coherent scattering in the ISOCS code. ${ }^{2}$

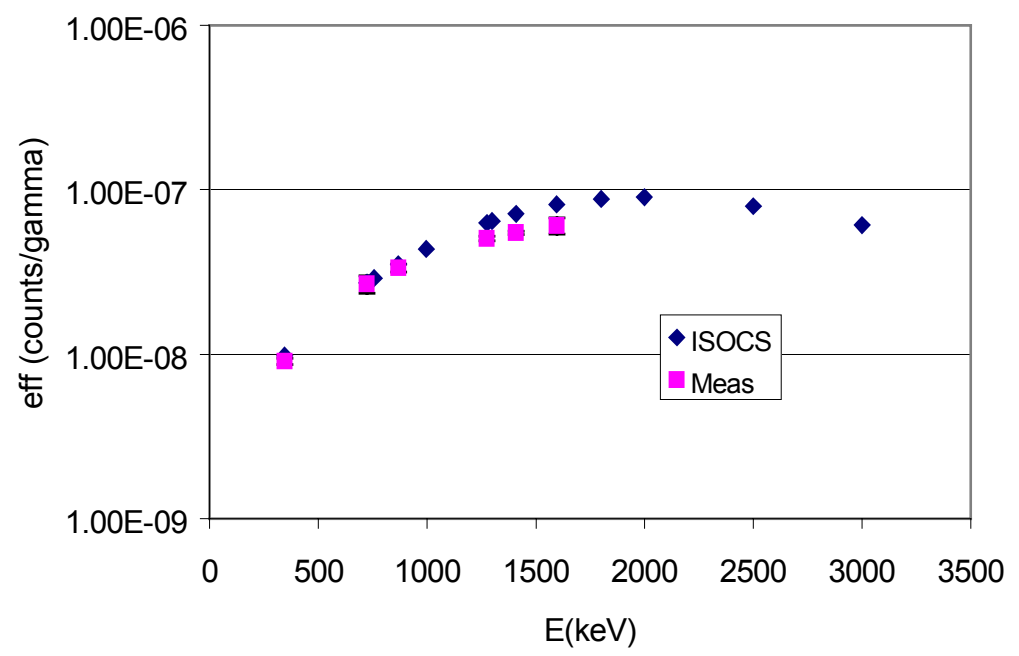

Figure 3. Comparison of ISOCS-calculated and measured detection efficiencies for the GSAK detector one meter from the overpack wall.

Because of the poor correlation between the measured and ISOCS-calculated detector efficiencies, the measured detector efficiency values were used for the GSAK surrogate calculations. The measured values were corrected for self attenuation in the water of the solution source and further corrected for the $1.2 \mathrm{~cm}(0.5 \mathrm{inch})$ difference in steel shield wall thickness. Self-attenuation corrections were calculated following published techniques for a right circular cylinder. ${ }^{4}$ The shield wall thickness difference was treated as a slab attenuator. The product of these two correction factors was used as a multiplicative factor to correct the efficiency values measured on the solution source in the 7.6-cm thick shield to an nonattenuating "zero matrix" drum within an $8.9-\mathrm{cm}$ thick shield. To verify the correction factor values, they were compared to the ratios of ISOCS-calculated efficiencies for the two measurement geometries. The correction factors agreed to within 3\% with those determined from the ISOCS ratios. The attenuation-corrected efficiency curves for measurements at one and two meter distances are presented in Figure 4. The plotted error bars represent one estimated standard deviation. 


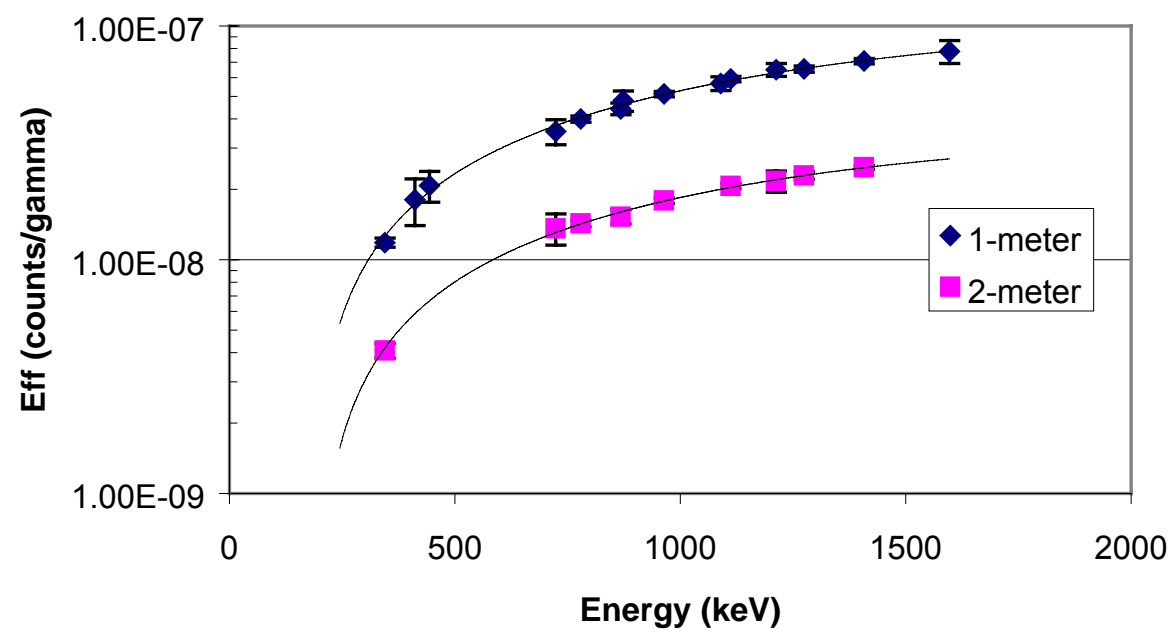

Figure 4. Efficiency curves for the GSAK detector at one and two meters from an overpacked zero matrix drum.

\section{The Surrogate Drum Configurations}

A set of three CC104/107 debris waste surrogate drums was configured for testing of NDA characterization techniques. Each surrogate drum incorporates a fixture to hold rods of matrix materials carefully selected to match the CC104/107 waste stream, and five source insertion guide tubes. The units are designed to mate to a hot cell port and receive source cartridge assemblies loaded with representative radioactive sources in a defined loading pattern. The development and design of the surrogate drums is described in detail elsewhere. 5 The available surrogate drums included one with a combustible matrix and two with a noncombustible matrix. These drums were arbitrarily labeled $\mathrm{C}, \mathrm{NC}$, and $\mathrm{Z}$, with the $\mathrm{C}$ drum being the combustible matrix drum.

The photograph of Figure 5 shows certain features of the combustible surrogate and its components. The spool assembly holds matrix material rods in locations that mimic the waste pails of the actual waste package. Radioactive sources are to be contained in Swagelok ${ }^{\circledR}$-sealed source capsules. (An example is at the bottom of the photo about in the middle.) The source capsules are held in an expanded metal source cartridge assembly (lower right) and spaced at selected elevations using spacer plugs (bottom center surrounding the source capsule). Each source cartridge assembly is in turn inserted into one of the five radially-spaced guide tubes that penetrate the spool assembly from top to bottom. The spool assembly fits into a stainless steel outer can that is capped and inserted into a lined 114-liter (30gallon) drum that in turn fits into a steel overpack.

\section{Test Sources and Their Placement}

The INEEL CC104/107 waste stream was primarily generated during metallurgical examination of EBR-II driver fuel elements. Consequently, the test sources used in configuring the surrogates for the GSAK testing were segments of an irradiated EBR-II driver fuel element. Chopping the fuel stack of the 


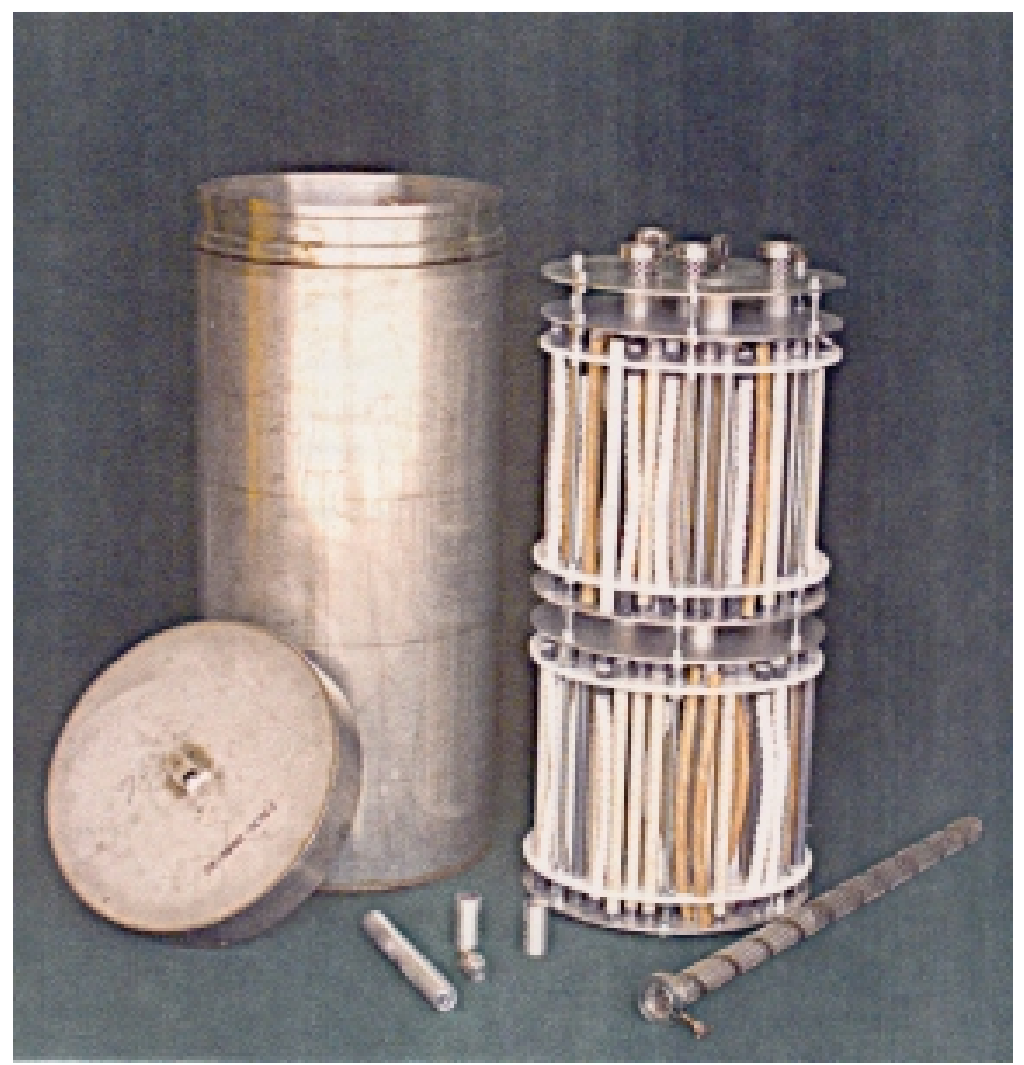

Figure 5. Preassembly photograph of the combustible matrix surrogate (Drum C).

spent EBR-II driver element J638 of subassembly X486 (Termed X486_J638) into 0.635-cm (0.25-inch) long segments produced thirty segments from which the test sources were chosen. The sources were sealed into source capsules and identified by numbers (SADY\#\#.)

Segment-specific inventory calculations were available (see next section) to guide the arrangement of source segments in the surrogate drums. Personnel exposure limits dictated the maximum source loading for a surrogate. These limits were determined by the allowable radiation dose both to personnel at the TREAT facility and to hot cell personnel during the source assembly loading. The GSAK test plan called for one surrogate configured with a symmetric source pattern at or near the allowable maximum dose rate, one with a symmetric loading pattern and an intermediate dose rate, and one surrogate with a highly asymmetric source loading. To accommodate these plans the $\mathrm{C}, \mathrm{NC}$, and $\mathrm{Z}$ surrogate drums were loaded with 8,6 , and 3 sources respectively. The $\mathrm{C}$ and $\mathrm{NC}$ drums were loaded symmetrically, while the three sources in the $\mathrm{Z}$ surrogate drum were loaded with one in the top center and two in the outside bottom. The source loading patterns for the $\mathrm{C}, \mathrm{NC}$, and $\mathrm{Z}$ source cartridge assemblies are depicted in Figures 6 through 8 respectively. In each surrogate, the source cartridge assembly 1 loads into the source guide tube at the radial center of the surrogate assembly, while source cartridge assembly 5 loads into the outermost guide tube. The source guide tubes are radially spaced so that when the assembly rotates, the source tubes sweep the usable interior volume of the surrogate assembly.

Elevations noted in Figure 6 through 8 are in inches above the bottom of the surrogate assembly. Source positions are identified by the source SADY number. Matrix-filled spacer plugs are identified with S numbers. Empty spacer plugs (SP) emulate the space between waste pails. For shielding purposes each source cartridge assembly is closed at the top with a 3-inch thick stainless steel shield plug (SS.) 


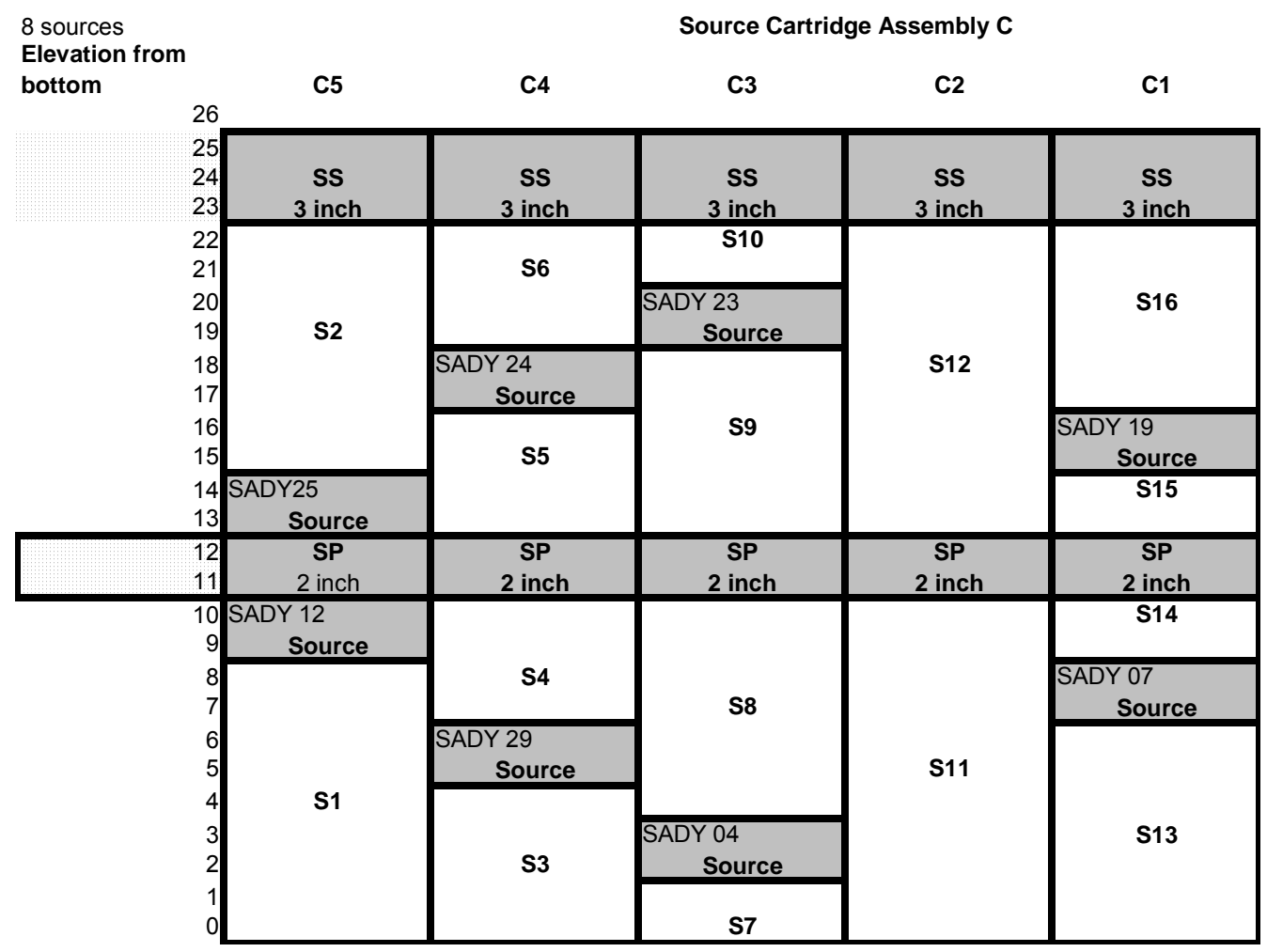

Figure 6. Source configuration in the combustible matrix surrogate drum C.

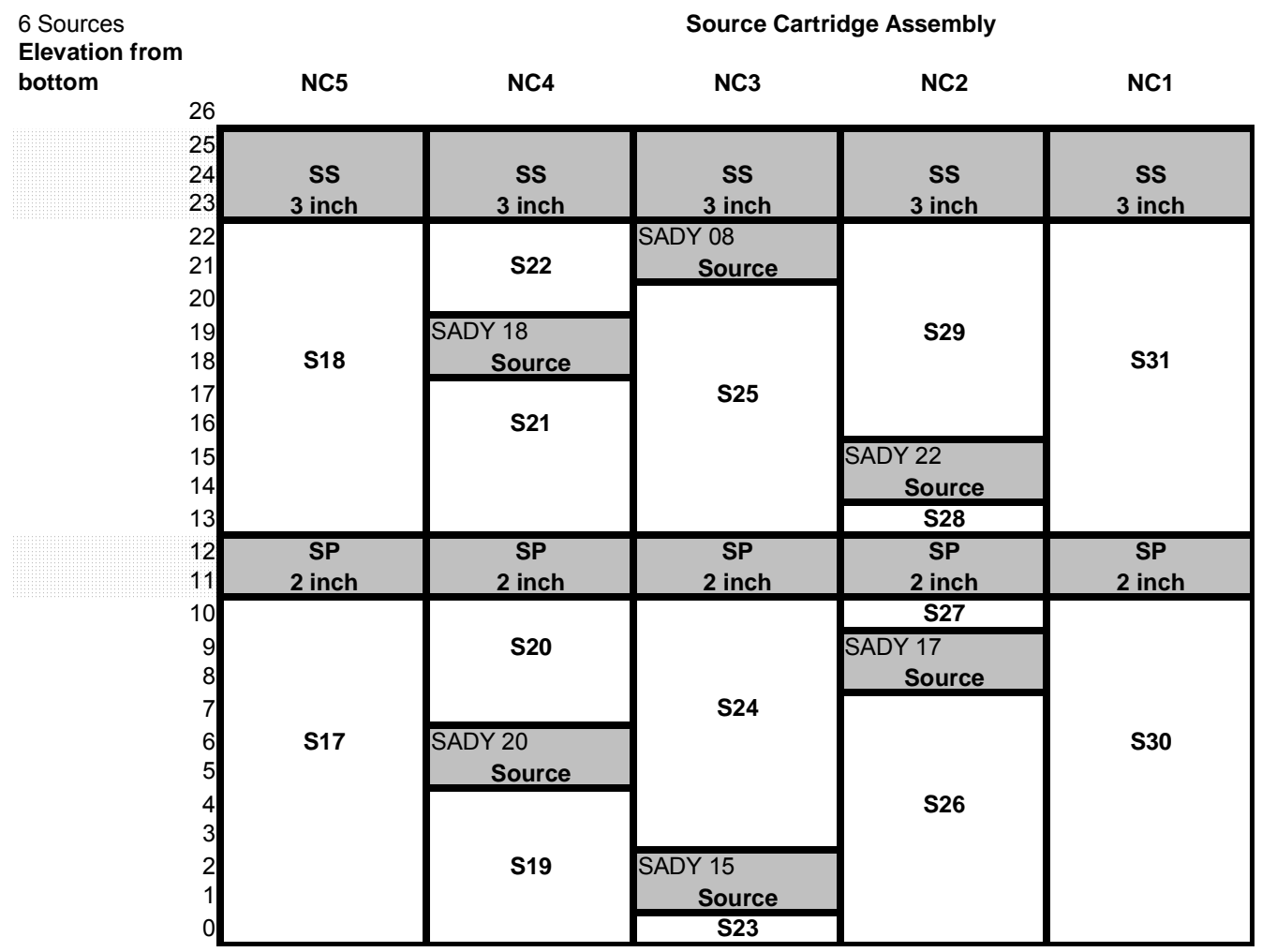

Figure 7. Source configuration in the noncombustible matrix surrogate drum NC. 


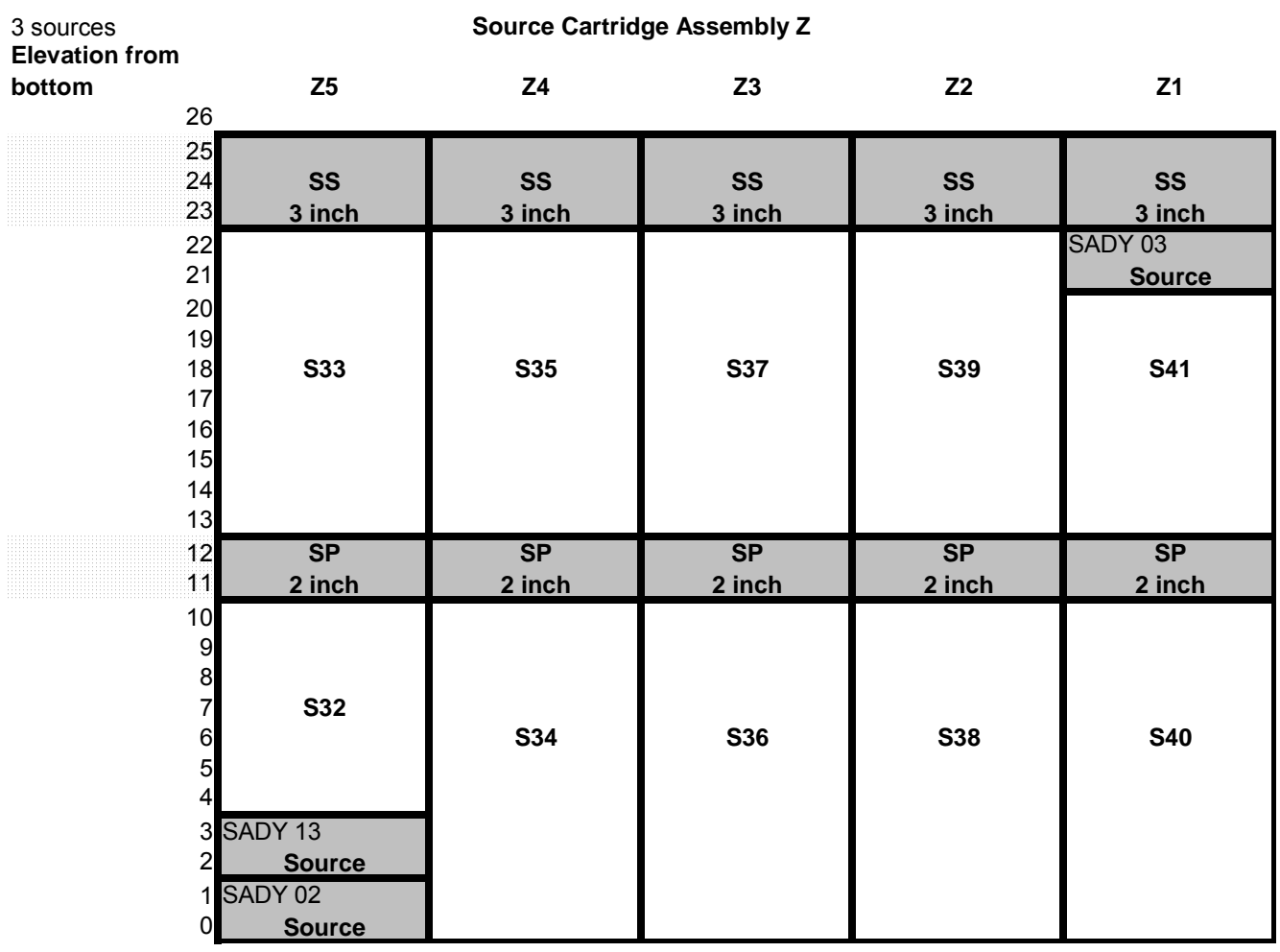

Figure 8. Source configuration in the noncombustible matrix surrogate drum Z.

\section{Inventory Calculations}

The inventory for given fuel segments was calculated using the standard computational methodology developed at Argonne National Laboratory for the calculation of post-irradiation compositions of EBR-II elements. This methodology was initially developed to support the Integral Fast Reactor project and later refined to support the Electro-Metallurgical Treatment of Spent Fuel Demonstration project. The method has been validated for EBR-II binary and ternary driver elements to a one-sigma uncertainty of $6 \%$ for total burn-up and $1.06 \%$ for heavy metal mass.

The methodology is a series of computations to first determine the flux at a given location and then use the flux information, along with the initial fuel compositions, to compute the isotopic mass distributions within a given element. Then a segment of the element is chopped and the isotopic composition is computed for a physical sample size from the axial distributions of each isotope.

Accurate predictions of the isotopic inventory of spent fuel in EBR-II require specification of the neutron irradiation field to which the assembly was expesed throughout its lifetime. For each reactor cycle of EBR-II, the REBUS-3 fuel cycle analysis code $\mathrm{Z}_{\text {was }}$ utilized to compute batch-averaged compositions for each specified depletion region. Within REBUS, calculations to predict the space and energy dependence of the neutron flux were performed by the DIF3D flux solution module ${ }^{8}$ using a threedimensional (hexagonal-Z) nodal diffusion method and a nine group energy structure. Burnup chains spanning the range from U-234 to Cm-246 are utilized in REBUS-3. Regien-dependent broad group cross-sections based on the ENDF/B-V.2 were generated using the MC2-2 2 and SDX ${ }^{10}$ codes for actual EBR-II fuel compositions.

Although the REBUS-3 computation accurately tracks the depletion and transmutation of the major actinides (including the generation of plutonium) within gross reactor regions, other means are 
needed to determine spatial isotopic detail within specific assemblies. The ORIGEN point depletion code 11 is used to track the transmutation and decay of 272 structural isotopes, 842 fission product isotopes, and 104 actinide isotopes for a user supplied flux history and initial composition. A modified version of ORIGEN (ORIGEN-RA), which allows cross-section data to be input at run time and utilizes updated library data, was utilized. The REBUS data is used to specify the in-reactor flux history, in which cross-sections are utilized in ISOTXS format.

The conventional fast reactor cross-section data used in the flux calculations, while appropriate for determining flux levels and gross region averaged actinide isotopics, is not particularly useful for determining specific fission product and activation product inventories. Specific cross-sections for individual activation products are not included in the REBUS ISOTXS data set and fission products are modeled as one material - commonly referred to as a fission product lump. These simplifications in the modeling still allow for accurate reactor physics modeling, however, they do not address the individual fission and activation product isotopes. To determine the correct fission product and activation product inventories, additional cross-section data are required and more detailed calculations have to be performed to determine the appropriate spatially-dependent cross-sections to be used in the ORIGEN calculations.

Since depletion isotopics are calculated at several axial levels of each pin in an assembly, a code was written to set up the multitude of ORIGEN input streams. Before any isotopic depletion calculations are performed, an assembly history file is generated. This file contains the assembly positional information, orientation, the integrated power, and the assumed power level of the reactor. The methodology allows for an assembly to be moved numerous times during its irradiation lifetime. The irradiation time, at any given reactor grid position, is inferred from the integrated power and the indicated power level in the assembly history file.

The code first reconstructs the fluxes (group-wise and total) at each of the axial levels and at each of the pin positions from the 3D hex-Z data. Calculations are performed at each axial level delineated in the nodal diffusion solution - about 180 ORIGEN calculations per assembly per irradiation run for a driver assembly. Also calculated are the spatially-dependent, energy-integrated reaction rates for each of the nuclides in the ISOTXS cross-section set, which allows for the construction of spatially-dependent one-group effective cross-sections to be used in ORIGEN.

The ORIGEN-RA code is executed for each pin and at each axial level, for each of the irradiation segments pertinent to the pins of the specified assembly. ORIGEN-RA transmutes the nuclides in the input file to create the output file using user-supplied fluxes and light isotope, actinide, and fission product cross-section libraries. After each irradiation run, the input file for the next ORIGEN-RA calculation is set up using the output file from the previous irradiation run until all of the irradiation runs for the axial level are completed. This process is then repeated for each axial level until the entire pin is completed. These calculations provide point-wise isotopic data for each axial level of the pin. The pointwise data are then used to generate axial profiles for each isotope in the pin. These profiles, referred to as one-dimensional ISO-Z files, are retained as the record of the isotopic inventory of the pin. To use the one-dimensional data, a code called CHOPIT is then used to generate a zero-dimensional ISO-Z file for a selected length of a pin.

\section{Surrogate Drum Activities}

Surrogate drum activity estimates were calculated by summing the inventory values for the segments arrayed in each drum. Table 2 presents the calculated inventories of some key radionuclides in the surrogate drums used for the GSAK test. The $\mathrm{C}, \mathrm{NC}$, and $\mathrm{Z}$ drums had calculated TRU concentrations of 703, 194, and $95 \mathrm{nCi}$ TRU/gram of matrix material respectively. 
Table 2. Calculated surrogate drum inventories of certain key radionuclides.

\begin{tabular}{cccc}
\hline & \multicolumn{3}{c}{ Total Curies per Surrogate Assembly (09-Sep-99) } \\
Isotope & C Surrogate & NC Surrogate & Z Surrogate \\
\hline Mn-54 & $1.36 \mathrm{E}-03$ & $9.99 \mathrm{E}-04$ & $5.11 \mathrm{E}-04$ \\
Co-60 & $7.17 \mathrm{E}-03$ & $5.38 \mathrm{E}-03$ & $2.71 \mathrm{E}-03$ \\
$\mathrm{Cs}-134$ & $3.03 \mathrm{E}-02$ & $2.31 \mathrm{E}-02$ & $1.16 \mathrm{E}-02$ \\
Cs-137 & $2.55 \mathrm{E}+00$ & $1.91 \mathrm{E}+00$ & $9.61 \mathrm{E}-01$ \\
Pr-144 & $5.46 \mathrm{E}-02$ & $4.10 \mathrm{E}-02$ & $2.06 \mathrm{E}-02$ \\
Eu-154 & $7.86 \mathrm{E}-03$ & $5.99 \mathrm{E}-03$ & $3.01 \mathrm{E}-03$ \\
Pu-239 & $3.06 \mathrm{E}-03$ & $2.29 \mathrm{E}-03$ & $1.16 \mathrm{E}-03$ \\
\hline
\end{tabular}

A set of four X486_J638 fuel segments were selected and sent to the ANL-W analytical laboratory for radiochemical analysis to confirm the calculated inventory values.

\section{Surrogate Drum Measurements at the TREAT Facility}

After the surrogate assemblies were loaded with sources in the specified pattern, they were transported using a mobile shielding cask to the TREAT facility. At TREAT, the surrogate assembly cans were transferred into lined 114-liter (30-gallon) drums prepositioned within their steel shielding overpacks, and the overpack lids secured. When a particular surrogate was to be measured, it was moved by crane to the GSAK inspection area and positioned on the heavy-duty rotator assembly. All drums were rotated during assay. The GSAK inspection area was more than 30 feet from the nearest shielded surrogate storage location. Figure 9 is a photograph taken during surrogate measurements at TREAT.

Each surrogate assembly was sequentially assayed. At least two spectra were acquired on each surrogate at an overpack-to-detector distance of 1 meter and at least two at an overpack-to-detector distance of 2 meters. Repetitive measurements on the $\mathrm{C}$ surrogate were preformed to determine the precision of the spectrometer positioning and its effect on the overall measurement precision. The detector was repositioned between each measurement. The measurement precision was evaluated by determining the peak counting rate in the $662 \mathrm{keV}$ line of ${ }^{137} \mathrm{Cs}$ in each spectrum. The standard deviation of this set of data provided an estimate of the measurement repeatability. The relative standard deviation of the measurements at 1 -meter and 2 -meter distances were $0.7 \%$ and $1.9 \%$ respectively. 


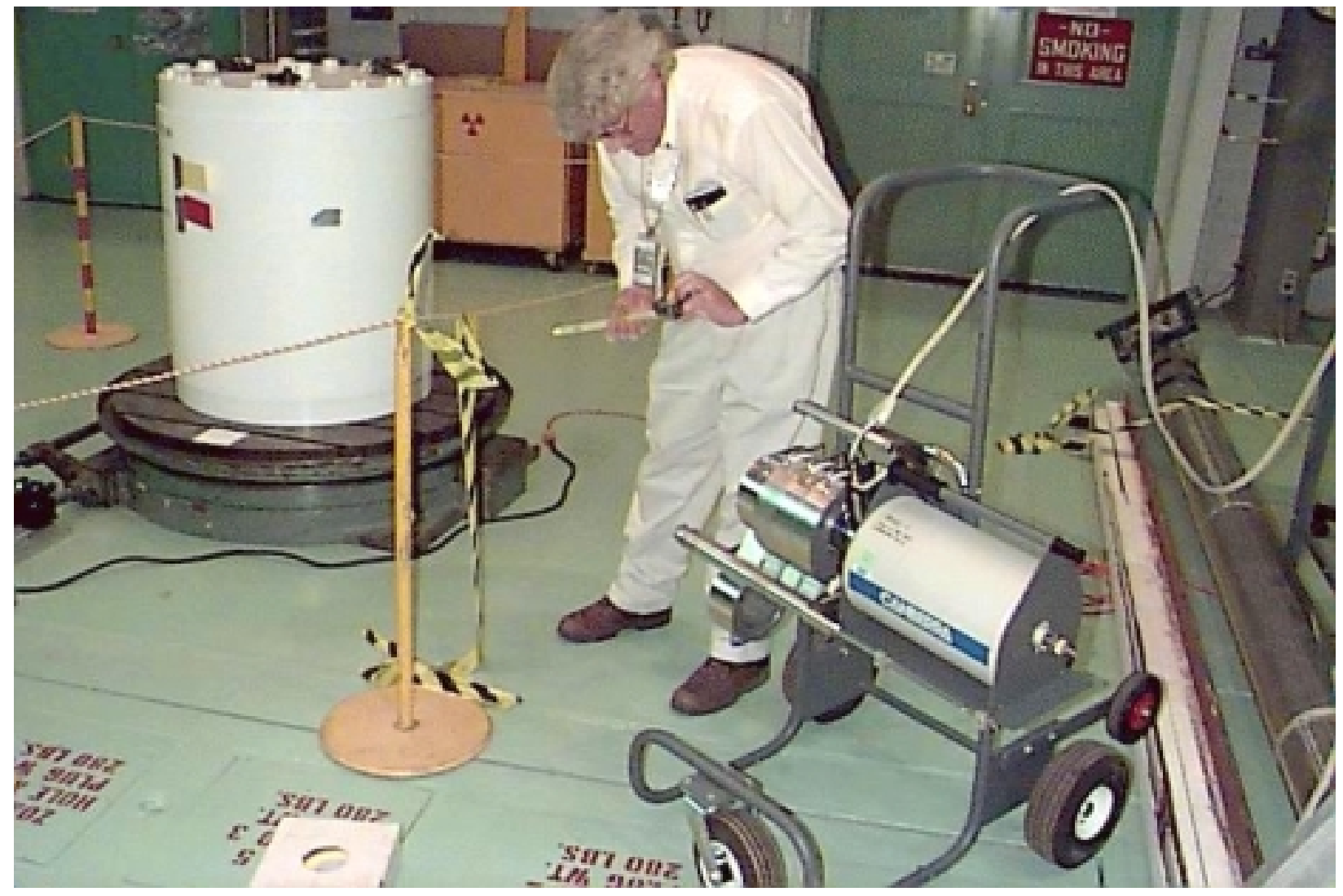

Figure 9. Photograph of a surrogate drum under assay by GSAK. The detector, detector shield and cart are visible in the foreground, while the surrogate in its steel overpack is visible in the background loaded onto the heavy-duty rotator.

\section{RESULTS}

\section{Radiochemical Segment Assays}

Segments SADY33, SADY26, SADY16, and SADY28 of driver fuel rod X486_J638 were submitted to the ANL-West Analytical Laboratory for radiochemical analysis to check on the accuracy of the inventory calculations. These segments represent inventories from near the top, the bottom and the center of the fuel element. Each segment was weighed as received, dissolved and the solution weight determined to allow accurate dilution factor corrections. Total $\mathrm{Pu}, \mathrm{Pu}$ isotopic ratios, total $\mathrm{U}$, and $\mathrm{U}$ isotopic ratios were determined by isotope dilution mass spectrometry. Total La and total Tc were determined by inductively coupled plasma emission spectroscopy. Gamma-ray spectrometry quantified the gamma-ray emitting activation and fission product content. All radioanalytical results were decay corrected to 08-Dec-99. The radioassay results on the analyzed segments are compared with their calculated inventory values (decay corrected to 08-Dec-99) in Table 3. 
Table 3. Comparison of the laboratory-measured radionuclide results with those calculated using the inventory codes for the four analyzed segments.

\begin{tabular}{|c|c|c|c|c|c|c|}
\hline \multirow[b]{2}{*}{ Segment } & \multirow[b]{2}{*}{ Isotopes } & \multicolumn{2}{|c|}{ Measured } & \multirow{2}{*}{$\frac{\text { Calculated }}{\mathrm{mCi} / \text { Segment }}$} & \multicolumn{2}{|c|}{ measured/calculated } \\
\hline & & $\mathrm{mCi} /$ Segment & $\%$ Error $(2 \sigma)$ & & Ratio & Error $( \pm 2 \sigma)$ \\
\hline \multirow[t]{24}{*}{ SADY33 } & Ce-144 & 5.40 & $18.0 \%$ & 5.35 & 1.01 & 0.21 \\
\hline & Co-60 & 0.21 & $19.0 \%$ & 0.85 & 0.25 & 0.05 \\
\hline & Cs-134 & 1.50 & $15.0 \%$ & 3.48 & 0.43 & 0.08 \\
\hline & Cs-137 & 130.00 & $15.0 \%$ & 307.66 & 0.42 & 0.08 \\
\hline & Eu-154 & 0.91 & $19.0 \%$ & 0.96 & 0.94 & 0.20 \\
\hline & Eu-155 & 4.00 & $18.0 \%$ & 5.59 & 0.71 & 0.15 \\
\hline & $\mathrm{Mn}-54$ & 0.16 & $33.0 \%$ & 0.13 & 1.26 & 0.43 \\
\hline & Ru/Rh-106 & 3.20 & $20.0 \%$ & 2.81 & 1.14 & 0.25 \\
\hline & Sb-125 & 3.90 & $19.0 \%$ & 4.82 & 0.81 & 0.17 \\
\hline & & w/o & $\%$ Error $(2 \sigma)$ & w/o & & \\
\hline & Pu-238 & 0.24 & $2.0 \%$ & $0.3 \%$ & 0.84 & 0.09 \\
\hline & Pu-239 & 98.66 & $0.5 \%$ & $96.9 \%$ & 1.02 & 0.10 \\
\hline & Pu-240 & 1.09 & $2.0 \%$ & $1.0 \%$ & 1.09 & 0.11 \\
\hline & Pu-241 & $<0.005$ & $\mathrm{n} / \mathrm{a}$ & $0.0060 \%$ & na & na \\
\hline & Pu-242 & $<0.002$ & $\mathrm{n} / \mathrm{a}$ & $0.0001 \%$ & na & na \\
\hline & $\mathrm{U}-234$ & 0.73 & $2.0 \%$ & $0.7 \%$ & 1.01 & 0.10 \\
\hline & U-235 & 62.60 & $0.5 \%$ & $62.4 \%$ & 1.00 & 0.10 \\
\hline & U-236 & 2.31 & $1.0 \%$ & $2.3 \%$ & 1.00 & 0.10 \\
\hline & U-238 & 34.36 & $0.5 \%$ & $34.6 \%$ & 0.99 & 0.10 \\
\hline & & $\mathrm{mg} / \mathrm{sample}$ & $\%$ Error $(2 \sigma)$ & $\mathrm{mg}$ & & \\
\hline & Total Pu & 6.40 & $0.5 \%$ & 6.17 & 1.04 & 0.10 \\
\hline & Total U & 1231.00 & $0.5 \%$ & 1146.25 & 1.07 & 0.11 \\
\hline & La & 4.40 & $5.0 \%$ & na & na & na \\
\hline & Tc & na & na & na & na & na \\
\hline \multirow[t]{24}{*}{ SADY26 } & Ce-144 & 4.70 & $22.0 \%$ & 5.63 & 0.83 & 0.20 \\
\hline & Co-60 & 0.19 & $17.0 \%$ & 0.89 & 0.21 & 0.04 \\
\hline & Cs-134 & 1.70 & $15.0 \%$ & 3.60 & 0.47 & 0.09 \\
\hline & Cs-137 & 130.00 & $15.0 \%$ & 324.48 & 0.40 & 0.07 \\
\hline & Eu-154 & 0.41 & $23.0 \%$ & 0.99 & 0.41 & 0.10 \\
\hline & Eu-155 & 2.00 & $16.0 \%$ & 5.92 & 0.34 & 0.06 \\
\hline & $\mathrm{Mn}-54$ & 0.13 & $31.0 \%$ & 0.15 & 0.89 & 0.29 \\
\hline & Ru/Rh-106 & 2.70 & $30.0 \%$ & 2.99 & 0.90 & 0.29 \\
\hline & Sb-125 & 3.40 & $22.0 \%$ & 5.08 & 0.67 & 0.16 \\
\hline & & w/o & $\%$ Error $(2 \sigma)$ & w/o & & \\
\hline & Pu-238 & 0.22 & $2.0 \%$ & $0.3 \%$ & 0.83 & 0.08 \\
\hline & Pu-239 & 98.72 & $0.5 \%$ & $95.3 \%$ & 1.04 & 0.10 \\
\hline & Pu-240 & 1.05 & $1.0 \%$ & $1.0 \%$ & 1.09 & 0.11 \\
\hline & Pu-241 & $<0.005$ & $\mathrm{n} / \mathrm{a}$ & $0.0057 \%$ & na & na \\
\hline & Pu-242 & $<0.001$ & $\mathrm{n} / \mathrm{a}$ & $0.0001 \%$ & na & \\
\hline & U-234 & 0.73 & $2.0 \%$ & $0.7 \%$ & 1.01 & na \\
\hline & U-235 & 62.75 & $0.5 \%$ & $62.6 \%$ & 1.00 & 0.10 \\
\hline & U-236 & 2.25 & $1.0 \%$ & $2.3 \%$ & 0.99 & 0.10 \\
\hline & U-238 & 34.27 & $0.5 \%$ & $34.6 \%$ & 0.99 & 0.10 \\
\hline & & $\mathrm{mg} / \mathrm{sample}$ & $\%$ Error $(2 \sigma)$ & $\mathrm{mg} / \mathrm{sample}$ & & \\
\hline & Total Pu & 5.40 & $0.5 \%$ & 6.06 & 0.89 & 0.09 \\
\hline & Total U & 1074.00 & $0.5 \%$ & 1147.94 & 0.94 & 0.09 \\
\hline & $\mathrm{La}$ & 3.90 & $5.0 \%$ & na & na & na \\
\hline & Tc & na & na & na & na & na \\
\hline
\end{tabular}


Table 3 (continued)

\begin{tabular}{|c|c|c|c|c|c|c|}
\hline \multirow[b]{2}{*}{ Segment } & \multirow[b]{2}{*}{ Isotope } & \multicolumn{2}{|c|}{ Measured } & \multirow{2}{*}{$\frac{\text { Calculated }}{\mathrm{mCi} / \text { Segment }}$} & \multicolumn{2}{|c|}{ measured/calculated } \\
\hline & & $\mathrm{mCi} /$ Segment & $\%$ Error $(2 \sigma)$ & & Ratio & Error $( \pm 2 \sigma)$ \\
\hline \multirow[t]{24}{*}{ SADY16 } & Ce-144 & 4.70 & $21.0 \%$ & 5.63 & 0.83 & 0.19 \\
\hline & Co-60 & 0.19 & $23.0 \%$ & 0.89 & 0.21 & 0.05 \\
\hline & Cs-134 & 1.70 & $15.0 \%$ & 3.60 & 0.47 & 0.09 \\
\hline & Cs-137 & 140.00 & $15.0 \%$ & 324.48 & 0.43 & 0.08 \\
\hline & Eu-154 & 0.49 & $36.0 \%$ & 0.99 & 0.49 & 0.18 \\
\hline & Eu-155 & 2.00 & $16.0 \%$ & 5.92 & 0.34 & 0.06 \\
\hline & Mn-54 & 0.14 & $23.0 \%$ & 0.15 & 0.96 & 0.24 \\
\hline & Ru/Rh-106 & 2.70 & $32.0 \%$ & 2.99 & 0.90 & 0.30 \\
\hline & Sb-125 & 3.80 & $29.0 \%$ & 5.08 & 0.75 & 0.23 \\
\hline & & w/o & $\%$ Error $(2 \sigma)$ & w/o & & \\
\hline & Pu-238 & 0.24 & $2.0 \%$ & $0.3 \%$ & 0.80 & 0.08 \\
\hline & Pu-239 & 98.67 & $0.5 \%$ & $98.7 \%$ & 1.00 & 0.10 \\
\hline & Pu-240 & 1.08 & $2.0 \%$ & $1.0 \%$ & 1.05 & 0.11 \\
\hline & Pu-241 & $<0.005$ & $\mathrm{n} / \mathrm{a}$ & $0.0063 \%$ & na & na \\
\hline & Pu-242 & $<0.001$ & $\mathrm{n} / \mathrm{a}$ & $0.0001 \%$ & na & na \\
\hline & $\mathrm{U}-234$ & 0.73 & $2.0 \%$ & $0.7 \%$ & 1.02 & 0.10 \\
\hline & U-235 & 62.52 & $0.5 \%$ & $62.0 \%$ & 1.01 & 0.10 \\
\hline & $U-236$ & 2.33 & $1.0 \%$ & $2.3 \%$ & 0.99 & 0.10 \\
\hline & U-238 & 34.42 & $0.5 \%$ & $34.5 \%$ & 1.00 & 0.10 \\
\hline & & $\mathrm{mg} / \mathrm{sample}$ & $\%$ Error $(2 \sigma)$ & & $\mathrm{mg} / \mathrm{sample}$ & \\
\hline & Total Pu & 6.14 & $0.5 \%$ & 6.28 & 0.98 & 0.10 \\
\hline & Total U & 1170.00 & $0.5 \%$ & 1141.47 & 1.02 & 0.10 \\
\hline & La & 4.10 & $5.0 \%$ & na & na & na \\
\hline & Tc & na & na & na & na & na \\
\hline \multirow[t]{24}{*}{ SADY28 } & Ce-144 & 5.00 & $24.0 \%$ & 5.63 & 0.89 & 0.23 \\
\hline & Co-60 & 0.20 & $21.0 \%$ & 0.89 & 0.22 & 0.05 \\
\hline & Cs-134 & 2.20 & $15.0 \%$ & 3.60 & 0.61 & 0.11 \\
\hline & Cs-137 & 170.00 & $15.0 \%$ & 324.48 & 0.52 & 0.09 \\
\hline & Eu-154 & 0.53 & $38.0 \%$ & 0.99 & 0.53 & 0.21 \\
\hline & Eu-155 & 2.50 & $21.0 \%$ & 5.92 & 0.42 & 0.10 \\
\hline & Mn-54 & 0.13 & $48.0 \%$ & 0.15 & 0.89 & 0.44 \\
\hline & $\mathrm{Ru} / \mathrm{Rh}-106$ & 2.50 & $27.0 \%$ & 2.99 & 0.84 & 0.24 \\
\hline & Sb-125 & 3.70 & $17.0 \%$ & 5.08 & 0.73 & 0.14 \\
\hline & & w/o & $\%$ Error $(2 \sigma)$ & w/o & & \\
\hline & Pu-238 & 0.25 & $2.0 \%$ & $0.3 \%$ & 0.80 & 0.08 \\
\hline & Pu-239 & 98.65 & $0.5 \%$ & $99.7 \%$ & 0.99 & 0.10 \\
\hline & Pu-240 & 1.10 & $2.0 \%$ & $1.1 \%$ & 1.04 & 0.11 \\
\hline & Pu-241 & $<0.005$ & $\mathrm{n} / \mathrm{a}$ & $0.0065 \%$ & na & na \\
\hline & Pu-242 & $<0.001$ & $\mathrm{n} / \mathrm{a}$ & $0.0001 \%$ & na & na \\
\hline & U-234 & 0.73 & $2.0 \%$ & $0.7 \%$ & 1.02 & 0.10 \\
\hline & U-235 & 62.42 & $0.5 \%$ & $61.8 \%$ & 1.01 & 0.10 \\
\hline & U-236 & 2.36 & $1.0 \%$ & $2.4 \%$ & 1.00 & 0.10 \\
\hline & U-238 & 34.35 & $0.5 \%$ & $34.5 \%$ & 1.00 & 0.10 \\
\hline & & mg/sample & $\%$ Error $(2 \sigma)$ & $\mathrm{mg}$ & & \\
\hline & Total Pu & 6.18 & $0.5 \%$ & 6.35 & 0.97 & 0.10 \\
\hline & Total U & 1159.00 & $0.5 \%$ & 1139.73 & 1.02 & 0.10 \\
\hline & La & 4.90 & $5.0 \%$ & na & na & na \\
\hline & Tc & na & na & na & na & na \\
\hline
\end{tabular}

The comparison of the radioassay results with the calculated segment specific inventories indicates that while the inventory codes do a good job of predicting the heavy metal ( $\mathrm{Pu}$ and $\mathrm{U}$ ) build up and depletion, they provide very inconsistent results on activation and fission product inventories, and generally overestimate these concentrations. 
The measured-to-calculated inventory ratios from the four analyzed segments were averaged in order to compute an isotope-specific correction factor to apply to the surrogate drum inventory values. An inverse variance-weighted averaging technique was used, and the reduced Chi Squared value $\left(\chi^{2} / d f\right)$ for each sample compared with its expected range (99\%) in order to identify outlier values. No outliers were detected in any of the sample sets. Table 4 presents the average inventory measured-to-calculated ratios for nuclides of interest for the GSAK work. Note that although the inventory calculations correctly predict the $\mathrm{U}$ and $\mathrm{Pu}$ content, and the inventory of certain fission and activation products (RuRh-106, $\mathrm{CePr}-144$, and $\mathrm{Mn}-54$ ) they underpredict the radiocesium and radioeuropium contents by about a factor of two, and underpredict the ${ }^{60} \mathrm{Co}$ content by about a factor of five.

Table 4. Average measured-to-calculated segment inventory ratios for selected isotopes.

\begin{tabular}{ccc}
\hline & \multicolumn{2}{c}{ Measured/Calculated Ratio } \\
\cline { 2 - 3 } Isotope & Average & Error $( \pm 1 \sigma)$ \\
\hline Mn-54 & 0.969 & 0.079 \\
Co-60 & 0.223 & 0.012 \\
RuRh-106 & 0.947 & 0.067 \\
Sb-125 & 0.755 & 0.019 \\
Cs-134 & 0.480 & 0.022 \\
Cs-137 & 0.436 & 0.020 \\
CePr-144 & 0.892 & 0.026 \\
Eu-154 & 0.519 & 0.038 \\
Eu-155 & 0.379 & 0.020 \\
& & \\
Total Pu & 0.964 & 0.024 \\
Tot U & 1.008 & 0.025 \\
\end{tabular}

\section{Gamma-ray Spectrometric Results}

The gamma-ray spectra acquired on each surrogate were analyzed using the PCGAP国 gamma-ray spectral analysis code. Quantified results were computed using the proper detector efficiency and an isotope library derived from a qualified nuclear data set. ${ }^{12}$ Activity values were decay corrected to 08 Sept-99.

Although, within the measurement uncertainties, no strong evidence of matrix-induced attenuation was noted (the higher energy gamma lines for an isotope didn't give consistently higher calculated activities), a default matrix attenuation correction was applied to the spectrometric results. These corrections were determined from the matrix weight and target composition and used the selfabsorption correction for a right circular cylinder. ${ }^{-1}$ The isotopic activities from all of the measurements on a given surrogate were averaged using an inverse variance weighted average. The measured activities are presented in Table 5 and compared with the calculated inventory values. 
Table 5. Gamma-ray spectral measurement results on the RH-TRU surrogates compared with the surrogate activity values expected from the inventory calculations.

\begin{tabular}{|c|c|c|c|c|c|c|c|c|}
\hline & \multirow[b]{2}{*}{ Isotope } & \multicolumn{3}{|c|}{$\begin{array}{c}\text { Gamma-ray Spectrometry } \\
\text { Results }\end{array}$} & \multicolumn{2}{|c|}{$\underline{\text { Calculated inventory }}$} & \multicolumn{2}{|c|}{$\begin{array}{l}\text { Measured/Inventory } \\
\text { Ratio }\end{array}$} \\
\hline & & $\begin{array}{l}\text { Average } \\
\text { Curies }\end{array}$ & $\begin{array}{l}\text { Error } \\
( \pm 1 \sigma)\end{array}$ & $\%$ RSD & Curies & $\begin{array}{l}\text { Est Error } \\
\qquad( \pm 1 \sigma)\end{array}$ & Ratio & $\begin{array}{l}\text { Error } \\
( \pm 1 \sigma)\end{array}$ \\
\hline \multirow[t]{7}{*}{ C Can } & Mn-54 & $1.25 \mathrm{E}-03$ & $2.64 \mathrm{E}-04$ & $21 \%$ & 1.36E-03 & 1.36E-04 & 0.92 & 0.22 \\
\hline & Co-60 & 1.17E-03 & 1.83E-04 & $16 \%$ & 7.17E-03 & 7.17E-04 & 0.16 & 0.03 \\
\hline & Sb-125 & 2.61E-02 & 3.33E-03 & $13 \%$ & 4.22E-02 & 4.22E-03 & 0.62 & 0.10 \\
\hline & Cs-134 & $1.65 \mathrm{E}-02$ & 1.90E-03 & $11 \%$ & 3.03E-02 & 3.03E-03 & 0.54 & 0.08 \\
\hline & Cs-137 & $1.13 E+00$ & 1.28E-01 & $11 \%$ & $2.55 E+00$ & $2.55 \mathrm{E}-01$ & 0.44 & 0.07 \\
\hline & CePr-144 & $4.21 \mathrm{E}-02$ & 5.26E-03 & $12 \%$ & 5.46E-02 & 5.46E-03 & 0.77 & 0.12 \\
\hline & Eu-154 & $3.81 \mathrm{E}-03$ & 4.02E-04 & $11 \%$ & $7.86 \mathrm{E}-03$ & $7.86 \mathrm{E}-04$ & 0.48 & 0.07 \\
\hline \multirow[t]{7}{*}{ NC Can } & $M n-54$ & 1.03E-03 & $1.41 \mathrm{E}-04$ & $14 \%$ & 9.99E-04 & 9.99E-05 & 1.03 & 0.17 \\
\hline & Co-60 & $1.02 \mathrm{E}-03$ & 1.22E-04 & $11 \%$ & 5.38E-03 & 5.38E-04 & 0.19 & 0.03 \\
\hline & Sb-125 & 2.07E-02 & 2.56E-03 & $12 \%$ & 3.16E-02 & 3.16E-03 & 0.65 & 0.10 \\
\hline & Cs-134 & $1.65 \mathrm{E}-02$ & 1.90E-03 & $11 \%$ & 2.31E-02 & 2.31E-03 & 0.72 & 0.11 \\
\hline & Cs-137 & $1.13 E+00$ & $2.58 \mathrm{E}-01$ & $23 \%$ & $1.91 \mathrm{E}+00$ & $1.91 \mathrm{E}-01$ & 0.59 & 0.15 \\
\hline & CePr-144 & 3.10E-02 & 3.80E-03 & $12 \%$ & 4.10E-02 & 4.10E-03 & 0.76 & 0.12 \\
\hline & Eu-154 & 2.90E-03 & $3.41 \mathrm{E}-04$ & $12 \%$ & 5.99E-03 & 5.99E-04 & 0.48 & 0.07 \\
\hline \multirow[t]{7}{*}{ Z Can } & Mn-54 & 4.43E-04 & 1.56E-04 & $35 \%$ & 5.11E-04 & 5.11E-05 & 0.87 & 0.32 \\
\hline & Co-60 & 4.53E-04 & 8.11E-05 & $18 \%$ & 2.71E-03 & 2.71E-04 & 0.17 & 0.03 \\
\hline & Sb-125 & 1.13E-02 & 1.46E-03 & $13 \%$ & 1.59E-02 & 1.59E-03 & 0.71 & 0.12 \\
\hline & Cs-134 & 7.59E-03 & 8.01E-04 & $11 \%$ & 1.16E-02 & 1.16E-03 & 0.65 & 0.10 \\
\hline & Cs-137 & 4.01E-01 & 1.17E-01 & $29 \%$ & 9.62E-01 & 9.62E-02 & 0.42 & 0.13 \\
\hline & CePr-144 & 1.34E-02 & 3.31E-03 & $25 \%$ & 2.07E-02 & 2.07E-03 & 0.65 & 0.17 \\
\hline & Eu-154 & 1.26E-03 & 1.68E-04 & $13 \%$ & 3.01E-03 & 3.01E-04 & 0.42 & 0.07 \\
\hline
\end{tabular}

The gamma-ray spectral results under predict the content of the surrogates relative to the calculated inventory values; however, the radiochemical assays performed on segments from this element determined that the inventory calculations over predict the content of many nuclides. The radiochemically-measured to calculated inventory ratios (see Table 4) were applied to the calculated inventory values to give adjusted inventory values for each surrogate. In Table 6, the gamma-ray spectrometric results are compared with these adjusted inventory values. In all cases, a $2 \sigma$ confidence limit constructed about the measured result includes the expected adjusted inventory value. 
Table 6. Gamma-ray spectral measurement results on the RH-TRU surrogates compared with the surrogate activity values expected from the inventory calculations adjusted using the radiochemical results.

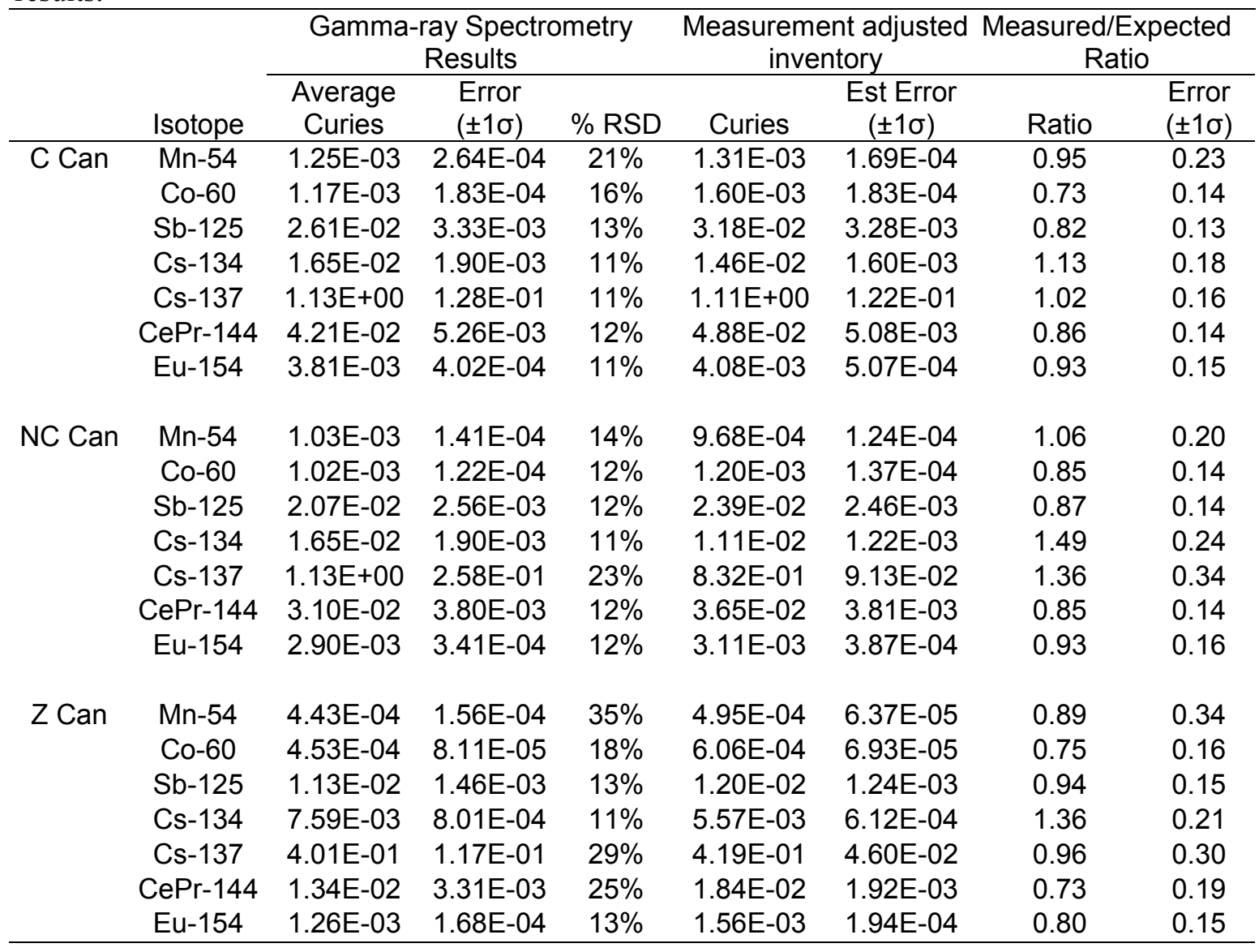

\section{DISCUSSION}

\section{RH-TRU Characterization}

The adequacy of candidate techniques to characterize RH-TRU waste must ultimately be judged against the appropriate transportation and disposal requirements. Although final for contact-handled TRU wastes, the transportation and disposal requirements for RH-TRU waste are currently in draft. $\frac{13,44}{\text { The }}$ draft WIPP waste acceptance criteria are summarized in Table 7. 
Table 7. Draft Quality Assurance Objectives for Radioassay measurements of RH-TRU wastes.

\begin{tabular}{|c|c|c|}
\hline & $D Q O$ & $Q A O$ \\
\hline 1 & $\begin{array}{l}\text { Waste contains }>100 \mathrm{nCi} \text { TRU isotopes } \\
\text { per gram of waste }\end{array}$ & $\begin{array}{l}\text { Measured value must be }>100 \mathrm{nCi} \text { per gram of waste using } \\
\text { a method with an MDL }<100 \mathrm{Nci} \text { per gram of waste. }\end{array}$ \\
\hline 2 & $\begin{array}{l}\text { Thermal power and/or decay heat limit to } \\
\text { maintain cask integrity. Upper limits are } \\
50 \text { Watts per canister for cellulosic wastes } \\
\text { and } 300 \text { Watts per canister for metallic } \\
\text { wastes }\end{array}$ & $\begin{array}{l}\text { For each canister, measured value plus the uncertainty is } \\
\text { less than the relevant limit. }\end{array}$ \\
\hline 3 & $\begin{array}{l}\text { Thermal power and/or decay heat limit to } \\
\mathrm{H}_{2} \text { generation }^{\mathrm{a}}\end{array}$ & $\begin{array}{l}\text { For each canister, measured value plus the uncertainty is } \\
\text { less than the relevant limit. }\end{array}$ \\
\hline 4 & $\begin{array}{l}{ }^{239} \mathrm{Pu} \text { FGE limit of }<325 \text { grams per } \\
\text { canister. }\end{array}$ & $\begin{array}{l}\text { For each canister, measured value plus the uncertainty on } \\
\text { the measurement must be }<325 \text { grams. }\end{array}$ \\
\hline 5 & PE-Ci limit of $<1000 \mathrm{Ci}$ per canister & $\begin{array}{l}\text { For each canister, measured value plus the uncertainty on } \\
\text { the measurement must be }<1000 \text { PE-Ci. }\end{array}$ \\
\hline 6 & $\begin{array}{l}\text { Activity }<23 \text { Curies per liter averaged } \\
\text { over the canister }\end{array}$ & $\begin{array}{l}\text { For each canister, measured average value plus the } \\
\text { uncertainty on the measurement must be }<23 \mathrm{Ci} / \text { liter. }\end{array}$ \\
\hline 7 & $\begin{array}{l}\text { Canister surface dose rate }<1000 \mathrm{Rem} / \mathrm{hr} \\
\text { for all waste; }<100 \mathrm{Rem} / \mathrm{hr} \text { for at least } \\
95 \% \text { of the } \mathrm{RH} \text { waste; and neutron } \\
\text { contribution to the surface dose rate }<270 \\
\mathrm{mrem} / \mathrm{hr} \text {. }\end{array}$ & $\begin{array}{l}\text { The measured value using an instrument calibrated } \\
\text { according methods and standards in NUREG-1575 (EPA } \\
\text { 402-R-97-016) or some other recognized relevant } \\
\text { procedure. }\end{array}$ \\
\hline 8 & $\begin{array}{l}\text { Radioisotopic content for shipping } \\
\text { manifest, PA, and LWA RH Curie limit. }\end{array}$ & $\begin{array}{l}\text { Quantify and report the } 10 \text { key radionuclides required by } \\
\text { the CCA and all other radioisotopes present at } 1 \% \text { (by } \\
\text { Curie) or greater. }\end{array}$ \\
\hline
\end{tabular}

The GSAK technique is unique in that most of the parameters important to RH-TRU waste characterization are not measured directly but are determined from the inventory calculations normalized by the gamma-ray spectral measurements.

\section{Minimum Detectable Concentration (MDC)}

The MDC of the GSAK system can be determined for detection of ${ }^{137} \mathrm{Cs}$, and with some assumptions regarding fuel burnup can be related to the MDC for TRU nuclides. One of the advantages of GSAK is that the detection sensitivity for fission product nuclides is very good due to their generally high gamma-ray intensities and the higher gamma-ray energies.

The MDC in nCi/gram of matrix for the GSAK system detection sensitivity for ${ }^{137} \mathrm{Cs}$ can be calculated from the basic detection limit equation.

$$
M D C=k_{1} k_{2}\left(2.71+4.65 S_{B}\right)
$$

where:

$\mathrm{MDC}=$ minimum concentration in $\mathrm{nCi} /$ gram detectable with $95 \%$ confidence

$\mathrm{k}_{1}=$ constant relating detector response to activity, includes the reciprocal of the product of the detector efficiency, the gamma-ray emission probability, and the counting time.

$\mathrm{k}_{2}=\quad$ constant relating the measured activity to a waste concentration, includes any absorption corrections not included in $\mathrm{k}_{1}$ and the reciprocal of the matrix weight.

$\mathrm{S}_{\mathrm{B}}=$ the estimated standard deviation of the background (in counts) for the count time chosen in $\mathrm{k}_{1}$. 
For the GSAK assay of CC104/107 drums at 1 meter distance and 1000 second count time, the $\mathrm{MDC}$ for ${ }^{137} \mathrm{Cs}$ is calculated as:

$$
\begin{aligned}
& \mathrm{k}_{1}=\quad[(2.51 \mathrm{E}-08 \mathrm{c} / \gamma)(0.852 \gamma / \mathrm{d})(1000 \mathrm{~s})]^{-1}=4.68 \mathrm{E}+04 \mathrm{~d} /(\mathrm{c} \cdot \mathrm{s}) \\
& \mathrm{k}_{2}=\quad \begin{array}{l}
{[0.027 \mathrm{nCi} /(\mathrm{d} / \mathrm{s})]\left(\mathrm{C}_{\mathrm{M}}\right)(\mathrm{W})^{-1} \text { where } \mathrm{C}_{\mathrm{M}} \text { is the default matrix absorption correction and } \mathrm{W} \text { is }} \\
\text { the matrix weight in grams }
\end{array} \\
& \mathrm{S}_{\mathrm{B}}=\quad(28)^{+0.5}=5.3 \text { counts }
\end{aligned}
$$

Thus, for the combustible waste matrix, $\mathrm{C}_{\mathrm{M}}=1.09$ and $\mathrm{W}=8107$ grams, thus:

$$
\mathrm{MDC}_{\mathrm{comb}}=[4.68 \mathrm{E}+04]\left[(0.027)(1.09)(8107)^{-1}\right][2.71+(4.65)(5.3)]=4.6 \mathrm{nCi}^{137} \mathrm{Cs} / \mathrm{g}
$$

For the noncombustible waste matrix $\mathrm{C}_{\mathrm{M}}=1.34$ and $\mathrm{W}=22210$ grams, thus:

$$
\mathrm{MDC}_{\mathrm{non}}=[4.68 \mathrm{E}+04]\left[(0.027)(1.34)(22210)^{-1}\right][2.71+(4.65)(5.3)]=2.1 \mathrm{nCi}^{137} \mathrm{Cs} / \mathrm{g} \text {. }
$$

For the surrogates used in this work, which have been loaded with fairly typical EBR-II fuel materials, the nominal total TRU-to $-{ }^{137} \mathrm{Cs}$ activity ratio is $5.2 \mathrm{E}-03\left(0.0057 \mathrm{Ci}\right.$ TRU/1.1 $\left.\mathrm{Ci}{ }^{137} \mathrm{Cs}\right)$, thus GSAK MDCs for Total TRU activity can be estimated as:

$$
\begin{aligned}
& \mathrm{MDC}_{\text {comb }}=\left(4.6 \mathrm{nCi}{ }^{137} \mathrm{Cs} / \mathrm{g}\right)\left(0.0052 \mathrm{TRU} /{ }^{137} \mathrm{Cs} \text { activity ratio }\right)=0.024 \mathrm{nCi} \text { TRU } / \mathrm{g} \\
& \mathrm{MDC}_{\text {non }}=\left(2.1 \mathrm{nCi}{ }^{137} \mathrm{Cs} / \mathrm{g}\right)\left(0.0052 \mathrm{TRU} /{ }^{137} \mathrm{Cs} \text { activity ratio }\right)=0.011 \mathrm{nCi} \mathrm{TRU} / \mathrm{g}
\end{aligned}
$$

Again, these TRU MDCs are for the specific irradiation conditions for the driver fuel element $\mathrm{x} 486 \mathrm{j} 638$. Irradiation condition differences that alter the TRU-to $-{ }^{137} \mathrm{Cs}$ activity ratio will alter the TRU MDCs. However, even at very slight burnups, the TRU $/{ }^{137} \mathrm{Cs}$ activity ratio will be $<1.0$. For example, in PWR fuels irradiated to only $1.0 \mathrm{GWda} / \mathrm{tU}$, the TRU/ $/{ }^{137} \mathrm{Cs}$ activity ratio is about 0.01 .6 As long as the TRU $/{ }^{137} \mathrm{Cs}$ activity ratio is less than 1 , MDCs for TRU using GSAK will be less than those calculated for ${ }^{137} \mathrm{Cs}$.

\section{GSAK Uncertainty Estimates}

Although, a full uncertainty analysis has not been performed, initial estimates of the GSAK measurement uncertainties can be developed from the measurements on the surrogate assemblies. The TRU content is determined from the gamma-ray spectral measurement of one or more key fission products (usually ${ }^{137} \mathrm{Cs}$ ) and knowledge of the fission product-to-TRU ratios either from inventory calculations or from radiochemical assay data. Thus, the overall GSAK bias can be estimated as the product of the measured-to-known ratio for ${ }^{137} \mathrm{Cs}$ times the estimated bias in the ${ }^{137} \mathrm{Cs}$ to ${ }^{239} \mathrm{Pu}$ ratio (assuming ${ }^{239} \mathrm{Pu}$ to be the TRU nuclide of primary importance). An estimate of the total GSAK precision can be derived from the gamma-ray spectral measurement precision and the estimated precision of the inventory ratios. The relative standard deviation (RSD) of the gamma-ray photopeak counting rate at 2 meters was determined to be $1.9 \%$ from repetitive measurements of ${ }^{137} \mathrm{Cs}$ on the $\mathrm{C}$ drum. The detector efficiency data has an estimated accuracy of about $\pm 12 \%$ in the ${ }^{137} \mathrm{Cs}$ energy region. A previous study, 15 concluded that even in the higher density non-combustible matrix drums, matrix attenuation corrections to the $662 \mathrm{keV}{ }^{137} \mathrm{Cs}$ gamma-ray can be made to $\pm 18 \%$ using default assumptions. Thus, presuming the source calibration to be unbiased, the measurements have an estimated accuracy of $1.0 \pm 0.22$. 
Estimating the system accuracy as the ratio of the ${ }^{137} \mathrm{Cs}$ measured to known values determined by measurements on each matrix-filled surrogate yields measured-to-inventory ratios of $0.44 \pm 0.07,0.59 \pm$ 0.15 , and $0.42 \pm 0.13$ for the $\mathrm{C}, \mathrm{NC}$, and $\mathrm{Z}$ surrogates when the calculated inventory values are used (Table 5.) If GSAK measurements were conducted without benefit of radiochemical assay and using the present inventory calculation scheme, this is the level of bias and precision that may be expected. While these results might satisfy the final quality objectives for RH-TRU wastes when they are finally formulated, they do not meet those presently in place for contact-handled TRU wastes.

However, when the radiochemically adjusted inventory values are used, the measured-to-known ${ }^{137} \mathrm{Cs}$ values for the $\mathrm{C}, \mathrm{NC}$, and $\mathrm{Z}$ surrogates are $1.02 \pm 0.16,1.36 \pm 0.34$, and $0.96 \pm 0.30$ respectively (Table 6.) These excellent results argue that the gamma-ray spectrometric measurements are accurate, but improvements may be required in the ability to estimate the inventory activity ratios.

\section{CONCLUSIONS}

The technique of gamma-ray spectroscopy with acceptable knowledge (GSAK) is an attractive technique for the characterization of CC104/107 RH-TRU wastes. The required measurements are rapid (a few 1000 seconds.) The equipment is simple and available "off the shelf." The work reported here on $\mathrm{CC} 104 / 107$ surrogates indicates that if accurate inventory isotopic ratios are available, the GSAK technique is capable of accurate, precise, and sensitive characterization of these waste forms.

However, at least for the driver fuel element used for these studies, the inventory calculations are inaccurate in their prediction of many fission and activation product inventories, and these inaccuracies are reflected in the GSAK results. While biases of $50 \%$ or more may be acceptable for RH-TRU characterization, it is not likely. Since, the limited number of surrogates available for this work were all derived from a single fuel element, the recoveries determined herein cannot be considered representative, and thus cannot be used to derive robust inventory correction factors.

The GSAK results on the three surrogates in this study could be improved by normalizing the inventory values using a fission product other than ${ }^{137} \mathrm{Cs}$. While the calculated inventory of ${ }^{137} \mathrm{Cs}$ is low by about $57 \%$, other minor nuclides such as ${ }^{144} \mathrm{Ce}\left({ }^{144} \mathrm{Pr}\right)$ and ${ }^{106} \mathrm{Ru}\left({ }^{106} \mathrm{Rh}\right)$ are better predicted. However, since all of the surrogates in this study contain segments from the same fuel pin, there is no guarantee that the same nuclides will be better predicted in all cases. Also, the GSAK gamma-ray spectra are absolutely dominated by the ${ }^{137} \mathrm{Cs}$ line, and it seems inappropriate to concentrate on minor lines in the spectrum for these normalizations.

One option for improving the accuracy of GSAK for the characterization of CC104/107 wastes is to determine the inventory calculation bias for the fission and activation products important to GSAK, and correct for these biases either in the GSAK inventory ratios or in the calculation scheme. The radioanalytical data on the driver fuel segments used to determine the accuracy of the heavy metal and burn up predictions of the inventory calculations also included fission and activation product activities; however, they were not analyzed to determine calculational biases. 16 This database could be used to calculate inventory correction factors and precisions for use in a GSAK characterization technique, or for cross-section library adjustments that would improve the accuracy of the inventory calculations.

A second option is to expand the acceptable knowledge records search to identify radioanalytical data either for the fuel elements sectioned to produce specific drum waste contents, or for companion elements in the same irradiation. For every sub-assembly that is removed from the EBR-II core, the central rod of that assembly is removed, sectioned at the core centerline, and analyzed radiochemically for total $\mathrm{Pu}, \mathrm{Pu}$ isotopics, total $\mathrm{U}$, Uranium isotopics, total $\mathrm{La}$, total $\mathrm{Tc}$, and the gamma-ray emitting activation and fission product nuclides. Inventory calculations are also performed to determine the 
calculated inventory of these rods. The measured-to-calculated ratios on these rods should be available to elucidate the accuracy of each inventory calculation.

Drum-specific isotopic ratios could be developed from a careful sampling effort during waste repackaging. Data from "swipes" or other samples might be used to improve the inventory ratio accuracy.

\section{REFERENCES}

${ }^{1}$ H. K. Peterson and C. R. Tyler, “Acceptable Knowledge Model for Remote-Handled Transuranic Waste Originating at Argonne National Laboratory and Stored at the Idaho National Engineering Laboratory (Content Code 104/107)," INEL/EXT-97-0232, May 1997.

${ }^{2}$ Canberra Industries, "ISOCS Calibration Software for GENIE 2000," S573-USR V1.2b, Canberra Industries, December 1997.

${ }^{3}$ E. W. Killian and L. V. East, "PCGAP: Application to Analyze Gamma-Ray Pulse-Height Spectra on a Personal Computer under Windows NT®," Proceedings of the Fourth International Conference on Methods and Applications of Radioanalytical Chemistry, Kona, HI, April 6-11, 1997.

${ }^{4}$ D. Reilly, N. Ensslin, H. Smith, Jr., and S. Kreiner Editors, Passive Nondestructive Assay of Nuclear Materials, LA-UR-90-732, March 1991.

${ }^{5}$ M. E. McIlwain, G. K. Becker, J. K. Hartwell, "Development of INEEL 104/106 Heterogeneous Debris Remote-Handled Waste Surrogates," Proceedings of the $7^{\text {th }}$ Nondestructive Assay Waste Characterization Conference, Salt Lake City, UT, May 2000.

${ }^{6}$ R. D. McKnight, "Validation of the REBUS-3/RCT Methodologies for EBR-II Core-Follow Analysis," Proceedings of the 1992 Topical Meeting on Advances in Reactor Physics, Vol.2 p. 69-80, Charleston, SC, March 1992.

${ }^{7}$ B. J. Toppel, “A User's Guide for the REBUS-3 Fuel Cycle Analysis Capability,: Argonne National Laboratory Report ANL-83-2, March, 1983.

${ }^{8}$ K. L. Derstine, "DIF3D: A Code to Solve One-, Two-, and Three-Dimensional Finite Difference Diffusion Theory Problems," Argonne National Laboratory Report, ANL-82-64, April 1984.

${ }^{9}$ H. Henryson, et al., "MC2-2: A Code to Calculate Fast Neutron Spectra and Multi-group CrossSections," Argonne National Laboratory Report, ANL-8144, June 1976.

${ }^{10}$ W. M. Stacy, et al., "A New Space-Dependent Fast-Neutron Multi-Group Cross-Section Preparation Capability,” Trans. Am. Nucl. Soc., 15:292, 1972.

${ }^{11}$ Oak Ridge National Laboratory, "ORIGEN: Isotope Generation and Depletion Code - Matrix Exponential Method," Radiation Safety Information Computational Center Report CCC-217, June, 1977.

${ }^{12}$ E. Browne and R. B Firestone, Table of Radioactive Isotopes, $7^{\text {th }}$ Edition, V. S. Shirley, editor, John Wiley and Sons New York, 1986 (electronic version). 
${ }^{13}$ Draft Issue Paper, "Proposed Quality Assurance Objectives (QAOs) and Data Quality Objectives (DQOs) for Characterization of Remote-Handled (RH) Transuranic (TRU) Waste Going to the Waste Isolation Pilot Plant (WIPP) (1999).

${ }^{14}$ Benchmark Environmental Corporation, "DRAFT Annotated Outline for the WIPP Remote Handled Transuranic Waste Analysis Plan”, January 2000.

${ }^{15}$ J. K. Hartwell, W. Y. Yoon, and H. K. Peterson, "A Preliminary Evaluation of Certain Candidate NDA/NDE Techniques for RH-TRU Characterization,” INEL-96/0233, March 1997.

${ }^{16}$ R. D. McKnight, "Incorporation of Measurement Data from Irradiated Fuel Samples into the Mass Tracking System," Proceedings of the International Conference on the Physics of Nuclear Science and Technology, Vol. 2, p. 1661-1667, Long Island, NY, October 1998. 